\title{
Health Effects of Climate Change
}

\begin{tabular}{c}
\hline Andy Hain \\
\hline Jonathan A \\
\\
\\
\end{tabular} fostered by the use of fossil fuels but the accompanying accumulation of greenhouse gases, particularly carbon dioxide and methane, has implications for the world's climate (BOx). ${ }^{1}$ Since the 1850 s when temperature records began, the world has warmed by approximately $0.6^{\circ} \mathrm{C}$, largely in the last 3 decades. The United Nations Intergovernmental Panel on Climate Change (IPCC) projects an increase of between $1.8^{\circ} \mathrm{C}$ and $5.8^{\circ} \mathrm{C}$ and an increase in sea levels between 9 and $88 \mathrm{~cm}$ during the next century. ${ }^{1}$ Warming is likely to be greater at the poles than at the equator. The residence time in the atmosphere of carbon dioxide exceeds 100 years; therefore, our actions affect the prospects of future generations.

The IPCC concluded, "There is now good evidence that regional changes in climate, particularly increases in temperature, have already affected a diverse set of physical and biological systems in many parts of the world." Earlier break-up of ice on rivers and lakes and movements of plant and animal ranges to higher altitudes are some examples. There is also potential for large-scale and potentially irreversible changes in Earth systems, such as slowing of the ocean circulation that transports warm water to the North Atlantic, large-scale melting of the Greenland and west Antarctic ice sheets, and ac-

CME available online at www.jama.com celerated global warming because of the positive feedbacks of the carbon cycle (eg, methane released from thawing arctic tundra). The probability of these events may be very low but is likely to be affected by the speed and duration of climate change. The potential pathways by which climate change may affect health are shown in the FIGURE. ${ }^{2}$

\section{Thermal Stress}

Major increases in the frequency of heat waves with climate change may occur. For example in England, the heat wave of 1976 was a very rare event (occurring once every 310 years) that will probably occur every 5 to 6 years by 2050. ${ }^{3}$ The urban heat island effect results in the temperatures being somewhat higher in cities than in suburban and rural areas, primarily because of the abundance of heat-retaining surfaces such as concrete and black asphalt. In 1995, the week-long heat wave in Chicago, Ill, caused more than 700 heatrelated deaths. ${ }^{4}$ Much of the excess mortality from heat waves is related to cardiovascular, cerebrovascular, and respiratory disease and is concentrated in elderly persons and individuals with preexisting illness. A proportion of these deaths occur in susceptible people who are likely to have died in the near future but there also may be substantial numbers of potentially preventable deaths. The thousands who died in the recent European heat wave show current failings in dealing with this threat. $^{5}$

In the United States, cities with cooler climates tend to experience more heatrelated deaths than those with warmer climates $^{6,7}$ because populations can acclimatize to some extent to different levels of temperature. Acclimatization is through a range of mechanisms, physiological, behavioral, technological, but it is not yet clear how much such processes will diminish the adverse effects of climate change. The extent to which increases in heat-related mortality will be offset by reductions in cold-related mortality is likely to vary by location.

\section{Floods and Droughts}

Populations in developing countries are likely to be particularly vulnerable to floods because of the habitation of highrisk areas, such as flood plains and coastal zones, weak public health infrastructure, and proportionally higher economic damage. The health impacts include physical injury and increases in diarrheal diseases, particularly in developing countries where malnutrition may also increase. Increased incidence of respiratory infections may be caused by crowding of populations. Overgrowth of molds may also cause respiratory symptoms. Increases in psychiatric disorders, such as anxiety and depression, often occur, probably related to damage to the home environment and economic losses. Increases in suicide have been reported and behavioral disorders may increase in children. ${ }^{8}$ An increase in sea levels would pose even added risks to coastal communities.

Drought may have an impact on health in developing countries be-

Author Affiliations: London School of Hygiene and Tropical Medicine, London, England (Dr Haines); Department of Environmental Health Sciences, Johns Hopkins Bloomberg School of Public Health, Baltimore, Md (Dr Patz).

Corresponding Author and Reprints: Jonathan A. Patz, MD, MPH, Department of Environmental Health Sciences, Johns Hopkins School of Hygiene and Public Health, 615 N Wolfe St, Baltimore, MD 21205 (e-mail: jpatz@jhsph.edu).

Contempo Updates Section Editor: Sarah Pressman Lovinger, MD, Fishbein Fellow. 


\section{Box. Projected Changes During the 21st Century in Extreme Climate Phenomena and Their Likelihood*}

\section{Simple Extremes}

Higher maximum temperatures; more hot days and heat waves $\dagger$ over nearly all land areas (very likely

Higher (increasing) minimum temperatures; fewer cold days, frost days, and cold waves $\dagger$ over nearly all land areas (very likely $\ddagger$ )

More intense precipitation events (very likely $\ddagger$ over many areas)

\section{Complex Extremes}

Increased summer drying over most mid-latitude continental interiors and associated risk of drought (likely

Increase in tropical cyclone peak wind intensities, mean and peak precipitation intensities (likely $\ddagger$ over some areas)§

Intensified droughts and floods associated with El Niño events in many different regions (likely $\ddagger$ )

Increased Asian summer monsoon precipitation variability (likely $\ddagger$ )

Increased intensity of mid-latitude storms (little agreement between current models) $\dagger$

*Adapted with permission from Houghton et al. ${ }^{1}$ Likelihood refers to judgmental estimates of confidence used by the Intergovernmental Panel on Climate Change (IPCC) Working Group 1 in its Third Assessment Report.

$\dagger$ Information from the IPCC Working Group 1, Technical Summary. ${ }^{1}$

¥ummary for policy makers: very likely (90\%-99\% chance); likely (66\%-89\% chance).

$\S$ Changes in regional distribution of tropical cyclones are possible but have not been established.

cause of its adverse effects on food production and in hygiene because of use of water primarily for cooking rather than cleaning. Outbreaks of malaria can also occur during droughts as a result of changes in vector breeding sites.

\section{El Niño and Health}

El Niño events have probably occurred for millennia. The name arises from the observation that warm water appears off the coast of Peru and Ecuador, most noticeably around Christmas (El Niño thus refers to the infant Jesus). On an irregular basis between every 2 and 7 years, the warming is anomalous and persists for 12 to 18 months. It may be followed by a cold phase called La Niña. El Niño events are consistently associated with heavy rainfall and flooding on the west coast of Latin America but in addition have important distant linkages with climate in other parts of the world; this occurs because altered convection loops at the equator change weather patterns. For example, during El Niño years, drought usually occurs in South- east Asia, Indonesia, and southern Africa, whereas flooding may occur in the southwest United States, Argentina, and Kenya.

There have been a number of time series analyses during more than 1 event that suggest a range of impacts of the El Niño cycle on health. ${ }^{9}$ The most consistent relationships are with malaria epidemics in parts of Latin America and South Asia. The effects may be mediated by short-term atypical climatic conditions (eg, rainfall in arid regions and drought in more humid climates). The incidence of many other diseases, such as dengue, hantavirus infections, cholera, and Murray Valley encephalitis, may be influenced by El Niño, although the quality of the evidence is variable. ${ }^{9}$

There is a relationship between the El Niño phenomenon and the population affected by natural disasters, particularly droughts, on a global scale. ${ }^{10}$ It is not fully known how the El Niño phenomenon will be affected by climate change, but the IPCC has suggested that associated droughts and floods will be intensified (Box).

\section{Air Pollution}

The impact of some air pollutants on health appears to be stronger during summer months or during high temperatures, ${ }^{11}$ but this is not a universal finding. Ozone levels tend to be higher at higher temperatures and some studies have suggested that ozone contributes to the excess mortality observed. ${ }^{12}$

Climate change is likely to affect the risk of forest fires, which in some locations (eg, Malaysia and Brazil) have been associated with the increased risk of outpatient visits for respiratory disease. An increase in emergency department visits for asthma, bronchitis, and chest pain occurred after the 1998 wildfires in Florida. ${ }^{13}$

\section{Allergens}

Warmer winters may result in an earlier start of the grass pollen season, and birch pollen concentrations may also increase. Also, rising carbon dioxide has been shown to increase the timing and release of biogenic allergens (eg, ragweed) in both indoor and in situ studies. ${ }^{14} \mathrm{Cli}$ mate change may thus increase the incidence of allergic rhinitis, the intensity and duration of symptoms, or both. ${ }^{11}$

\section{Infectious Diseases}

Changes in temperature, humidity, rainfall, and sea level rise could all affect the incidence of infectious diseases. Mosquitoes, ticks, and fleas are sensitive to subtle temperature and humidity changes. But vector-borne diseases are also dependent on many other interacting factors. Although there has been a resurgence of infectious diseases in recent years, it is unclear that climate change has played a significant role. Other factors such as the movement of human and animal populations, the breakdown in public health infrastructure, changes in land use, and the emergence of drug resistance have been contributory. ${ }^{15}$

The TABLE illustrates the potential impacts of climate change on vectorborne and rodent-borne disease transmission, focusing on malaria and dengue. ${ }^{11}$ Malaria is currently present in 101 countries, and $40 \%$ of the world's 
population lives in areas with malaria. ${ }^{16}$ Malaria claims 1 to 2 million lives annually, most of which are those of children. In Africa, distribution of the disease is largely limited by climate, except at the southern limit. ${ }^{17}$ In many parts of the world, effective public health systems ensure that malaria transmission remains well within the climatic limits of its distribution. ${ }^{17}$

There are different approaches to modeling malaria risk with climate change, including biological models building from known disease transmission dynamics and statistical empirical approaches based on malaria's current epidemiology. A study using a biological model suggested, based on specific climate scenarios, that there might be a global increase of 260 to 320 million people in 2080 living in a potential transmission zone, against a baseline population expectation of about 8 billion. ${ }^{18}$
This represents a $2 \%$ to $4 \%$ increase in the number of people at risk of malaria.

Use of a statistical empirical approach suggested no significant net change by 2080 in the proportion of the world's population living in actual malaria transmission zones. ${ }^{19}$ But this approach may not capture potential climate change effects on the seasonality of malaria in areas where transmission already occurs.

Using the latest climate change scenarios, recent modeling experiments suggest a $5 \%$ to $7 \%$ potential increase in malaria distribution in Africa by 2100, primarily expanding malaria's altitudinal reach rather than latitudinal. An overall increase in person-months of exposure risk to malaria was $16 \%$ to $28 \%$, largely because of a prolonged transmission season. This most recent study used data that were spatiotemporally validated against parasite sur- veys and represents findings following extensive analysis. ${ }^{20}$

Climate change may contribute to the resurgence of malaria in areas where the public health infrastructure has broken down (eg, in central Asia and southern parts of the former Soviet Union). In regions where malaria has been locally eliminated but the vectors persist, there is a theoretical but small risk of localized outbreaks that could increase under climate change.

This is a topic of intense controversy and our understanding will continue to evolve as new research is conducted.

\section{Dengue Fever and Other Arboviruses}

The rate of dengue virus replication in Aedes aegypti mosquitoes increases directly with temperature in the laboratory. Biologically based models have been developed to explore the influence of

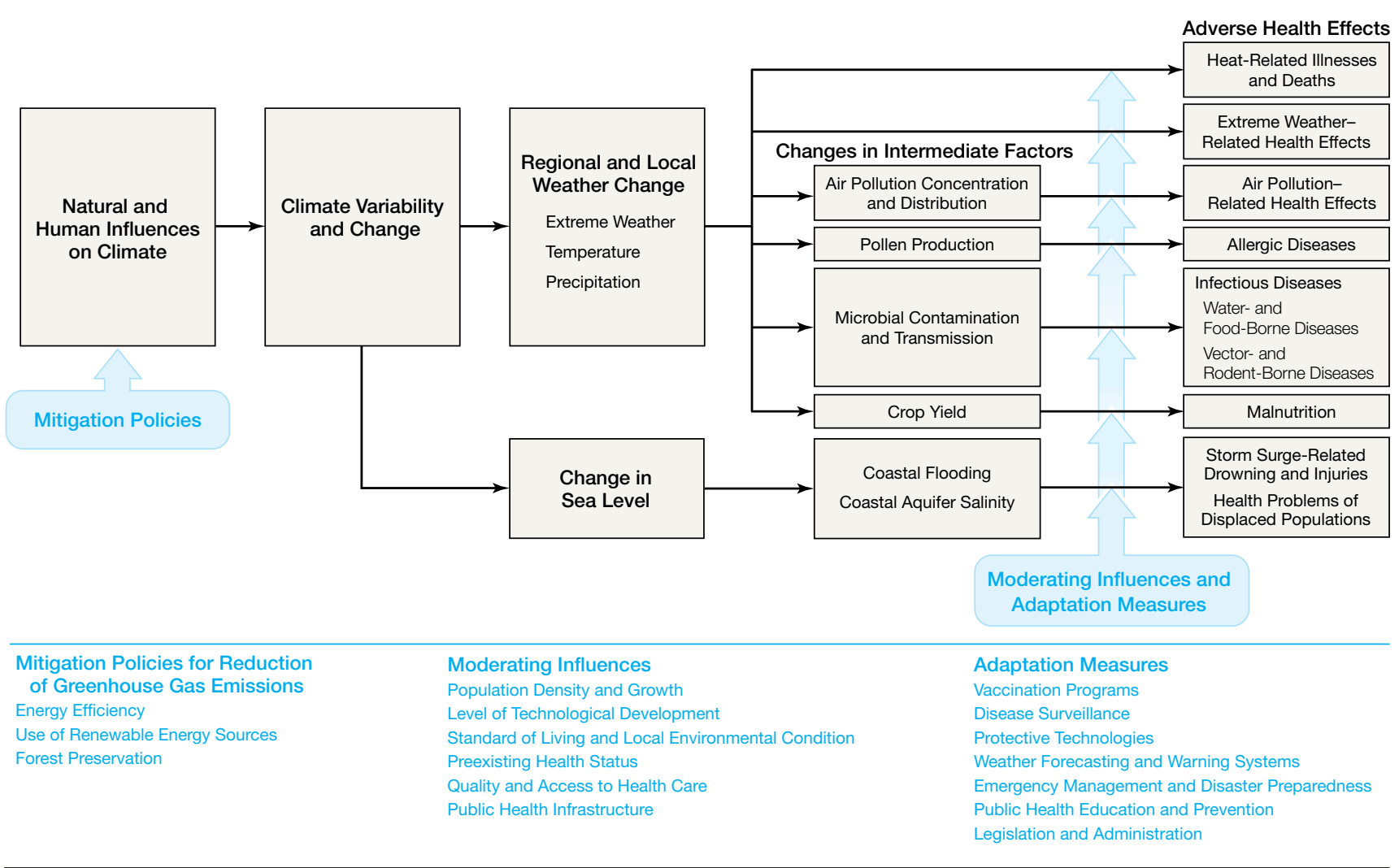

Adapted from Patz et al. ${ }^{2}$ Schematic of pathways through which climate change can affect multiple health outcomes. Examples are also given of moderating factors and adaptive measures determining extent of adverse outcomes, as well as mitigating measures to prevent global warming. 
projected temperature change on the incidence of dengue fever. When linked to future climate change projections, such models suggest that relatively small increases in temperature in temperate regions, given viral introduction into a susceptible human population, should increase the potential for epidemics. ${ }^{21}$

Epidemics of certain arboviral (mosquito-borne) encephalitides, such as Saint Louis encephalitis virus, and West Nile virus may be influenced by climatic factors. Both have been associated with drought conditions ${ }^{22}$ and when West Nile virus appeared in the United States in the summer of 1999 , the July temperatures in New York were the hottest on record. Outbreaks have also occurred in the Middle East and in eastern Europe following droughts.

\section{Leishmaniasis}

Leishmaniasis has become an important coinfection with human immunodeficiency virus in southern Europe and parts of Asia. There may be differences between vectors in susceptibility to climate change. For example, a study in Italy suggested that climate change could expand a range of one vector but decrease the range of another. ${ }^{11}$ Climate change could increase the geographical distribution of vectors in parts of Latin America and in southwest Asia.

\section{Tick-Borne Diseases}

There has been considerable interest in the potential impact of climate change on a number of tick-borne diseases, particularly Lyme disease, Rocky Mountain spotted fever, and tick-borne encephalitis. Temperature and humidity are important determinants of tick distribution. In Sweden, the extension of the northern limit of the distribution of the local tick vector ${ }^{23}$ and increased cases have been attributed to milder winters. A statistical model of tickborne encephalitis in Europe suggested that although disease foci could spread to higher latitudes and altitudes, the disease could largely disappear from central Europe because climate change would disrupt the complex life cycle of the tick. ${ }^{24}$ However, land use change, in addition to the burgeoning deer population in the eastern United States, may be responsible for the increased risk of Lyme disease..$^{25}$

\section{Rodent-Borne Diseases}

The emergence of hantavirus pulmonary syndrome in the southwest United States in 1993 may be linked to drought followed by El Niño-driven heavy rainfall resulting in growth in rodent populations and subsequent disease transmission. ${ }^{26}$ Extreme flooding or hurricanes can lead to outbreaks of leptospirosis. An epidemic of leptospirosis in Nicaragua followed heavy flooding in 1995. In a case-control study, a 15-fold risk of disease was associated with walking through flood waters. ${ }^{27}$

\section{Water-Related Diseases}

Worldwide more than 1 billion people lack access to safe drinking water. ${ }^{28}$ Modeling of impacts of climate change on water stress shows considerable variability between climate scenarios. Increased water stress is likely to occur in countries of southern and west Africa and in the Middle East. It is difficult however to relate this directly to the attributable risk of water-related diseases, although water scarcity may result in the use of more contaminated sources of fresh water because of combined use (same source for drinking, bathing, and irrigation). If in-

\begin{tabular}{|c|c|c|c|}
\hline Climate Factor & Vector & Pathogen & Vertebrate Host and Rodents \\
\hline Increases in temperature & $\begin{array}{l}\text { Decreased survival (eg, Culex tarsalis) } \\
\text { Change in susceptibility to some pathogens; } \\
\quad \text { seasonal effects } \\
\text { Increased population growth } \\
\text { Increased feeding rate to combat dehydration, } \\
\quad \text { therefore increased vector-human contact } \\
\text { Expanded distribution seasonally and spatially }\end{array}$ & $\begin{array}{l}\text { Increased rates of extrinsic } \\
\text { incubation in vector } \\
\text { Extended transmission season } \\
\text { Expanded distribution }\end{array}$ & Warmer winters favor rodent survival \\
\hline Decreases in precipitation & $\begin{array}{l}\text { Increase in container-breeding mosquitoes } \\
\text { because of increased water storage } \\
\text { Increased abundance for vectors that breed in } \\
\text { dried-up river beds } \\
\text { Prolonged droughts could reduce or eliminate } \\
\text { snail populations }\end{array}$ & No effect & $\begin{array}{l}\text { Decreased food availability can } \\
\text { reduce populations } \\
\text { Rodents may be more likely to move } \\
\text { into housing areas, increasing } \\
\text { human contact }\end{array}$ \\
\hline Increases in precipitation & $\begin{array}{l}\text { Increased rain increases quality and quantity } \\
\quad \text { of larval habitat and vector population size } \\
\text { Excess rain can eliminate habitat by flooding } \\
\text { Increased humidity increases vector survival } \\
\text { Persistent flooding may increase potential } \\
\quad \text { snail habitats downstream }\end{array}$ & $\begin{array}{l}\text { Little evidence of direct effects } \\
\text { Some data on humidity effect on } \\
\text { malarial parasite development } \\
\text { in Anopheline mosquito host }\end{array}$ & $\begin{array}{l}\text { Increased food availability and } \\
\text { population size }\end{array}$ \\
\hline $\begin{array}{l}\text { Increase in precipitation } \\
\text { extremes }\end{array}$ & $\begin{array}{l}\text { Heavy rainfall events can synchronize vector } \\
\text { host-seeking and virus transmission }\end{array}$ & No effect & $\begin{array}{l}\text { Risk of contamination of flood } \\
\text { waters or runoff with pathogens } \\
\text { from rodents or their excrement } \\
\text { (eg, Leptospira from rat urine) }\end{array}$ \\
\hline Sea-level rise & $\begin{array}{l}\text { Coastal flooding affects vector abundance for } \\
\text { mosquitoes that breed in brackish water } \\
\text { (eg, Anopheles subpictus and Anopheles } \\
\text { sundaicus malaria vectors in Asia) }\end{array}$ & No effect & No effect \\
\hline
\end{tabular}


creased flooding in winter months in parts of the world is accompanied by increased drying in summer months, a double burden of water-related diseases may result in some countries. Outbreaks of cryptosporidiosis have been related to heavy rainfall events in the United States and elsewhere. ${ }^{29}$

Warmer sea surface temperatures promote algal blooms that may be associated with cholera outbreaks. The incidence of cholera in Bangladesh in the earlier half of the last century (18931940) was uncorrelated with El Niño, although late in the century (1980-2001), the relationship was strong and consistent with strengthening El Niño events. ${ }^{30}$

\section{Malnutrition}

According to the United Nations Food and Agriculture Organization, approximately 790 million people in developing countries are malnourished. Studies of the effects of climate change on food production suggest that yields of cereal grains are likely to increase at high and mid-latitudes but decrease at lower latitudes. In particular, there is concern that climate change may adversely affect nutrition in Africa mainly because of increased drought conditions. ${ }^{11}$

\section{Mitigating Climate Change}

Mitigation refers to policies to reduce greenhouse gas emissions (eg, by promoting energy efficiency and the use of renewable energy sources such as solar and wind energy). This would especially apply to the United States, which produces more than $25 \%$ of global greenhouse emissions. ${ }^{31}$ Although discussion of greenhouse gas mitigation policy is beyond the scope of this article, medical personnel should recognize that reductions in greenhouse gas emissions will also likely provide near-term benefits via reductions in air pollution. The magnitude of the benefits will depend on the energy source that is being substituted (eg, the substitution of coal compared with natural gas as a fuel).

\section{Conclusions}

Physicians need to be aware of how current climate variability can affect health outcomes. They should also recognize that long-term climate change may exacerbate climate-sensitive health problems. Early warning systems for heat waves may reduce impacts and ensure that elderly persons, particularly those who are socially isolated, are monitored, offered access to air conditioning, and given advice about fluid intake and appropriate clothing. Climate change may affect the distribution of a number of infectious diseases and emerging infections that should be considered in the diagnosis of patients with unexplained symptoms. Physicians can also educate communities about the potential impacts of climate change, the need to improve current public health infrastructure, and participate in policies to decrease dependence on fossil fuels.

Climate change poses a range of challenges to human health, but many of the linkages are complex and a range of other social, behavioral, and environmental factors also affect the health outcomes in question. Because of the wide-ranging potential impacts of global warming, a precautionary approach should be taken that seeks to decrease greenhouse gas emissions substantially, including the introduction of energy efficiency and renewable energy technologies.

\section{REFERENCES}

1. Houghton JT, Ding Y, Griggs DJ, et al, eds. Climate Change 2001: The Scientific Basis. Cambridge, England: Cambridge University Press; 2001. 2. Patz JA, McGeehin MA, Bernard SM, et al. The potential health impacts of climate variability and change for the United States: executive summary of the report of the health sector of the US National Assessment. Environ Health Perspect. 2000;108:367-376.

3. Department of Health. Health Effects of Climate Change in the UK: Report of the Expert Advisory Group on Climate Change and Health, 2002. London, England: Dept of Health; 2002.

4. Whitman S, Good G, Donoghue ER, et al. Mortality in Chicago attributed to the July 1995 heat wave. Am J Public Health. 1997;87:1515-1518.

5. Dorozynski A. Heat wave triggers political conflict as French death rates rise. BMJ. 2003:327:411.

6. Chesnut LG, Breffle WS, Smith JB, Kalkstein LS. Analysis of differences in hot-weather-related mortality across 44 US metropolitan areas. Environ Sci Policy. 1998;1:59-70.

7. Kalkstein LS, Greene JS. An evaluation of climate/ mortality relationships in large US cities and the possible impacts of a climate change. Environ Health Perspect. 1997; 105:84-93.

8. Caffo E, Belaise C. Psychological aspects of traumatic injury in children and adolescents. Child Adolesc Psychiatr Clin North Am. 2003:12:493-535.

9. Kovats RS, Bourma MJ, Hajat S, Worrall E, Haines
A. El Niño and health. Lancet. 2003;362:1481-1489. 10. Bouma MJ Kovats RS, Goubet SA, Cox JS, Haines A. Global assessment of El Niño's disaster burden. Lancet. 1997;350:1435-1438.

11. McMichael M, Githeko A, Akhtar R, et al. Human health in climate change 2001: impacts, adaptation, and vulnerability. In: McCarthy J, Canziani OF, Leary NA, Dokken DJ, White KS, eds. Climate Change: Impacts, Adaptation, and Vulnerability: Contribu tion of Working Group II to the Intergovernmental Panel on Climate Changes. Cambridge, England: Cambridge University Press; 2001:451-485.

12. Thurston GD, Ito K. Epidemiological studies of acute ozone exposures and mortality. J Expo Anal Environ Epidemiol. 2001:11:286-294.

13. Surveillance of morbidity during wildfiresCentral Florida, 1998. MMWR Morb Mortal Wkly Rep. 1999:48:78-79.

14. Ziska LH. Evaluation of the growth response of six invasive species to past, present and future atmospheric carbon dioxide. J Exp Bot. 2003;54:395-404. 15. Patz JA, Graczyk TK, Geller N, Vittor AY. Effects of environmental change on emerging parasitic diseases. Int J Parasitol. 2000;30:1395-1405.

16. Greenwood B, Mutabingwa T. Malaria in 2002 Nature. 2002;415:670-672

17. Lindsay SW, Martens WJ. Malaria in the African highlands: past, present and future. Bull World Health Organ. 1998:76:33-45

18. Martens P, Kovats RS, Nijhof S, et al. Climate change and future populations at risk of malaria. Glob Environ Change. 1999:9:S89-S107.

19. Rogers DJ, Randolph SE. The global spread of malaria in a future, warmer world. Science. 2000;289 1763-1766.

20. Tanser FC, Sharp B, le Sueur D. Potential effect of climate change on malaria transmission in Africa. Lancet. 2003;362:1792-1798.

21. Patz JA, Martens WJ, Focks DA, Jetten TH. Dengue fever epidemic potential as projected by general circulation models of global climate change. Environ Health Perspect. 1998:106:147-153.

22. Epstein PR. West Nile virus and the climate. J Urban Health. 2001;78:367-371.

23. Lindgren $\mathrm{E}$, Talleklint L, Polfeldt T. Impact of climatic change on the northern latitude limit and population density of the disease-transmitting European tick ixodes ricinus. Environ Health Perspect. 2000;108:119-123.

24. Randolph SE, Rogers DJ. Fragile transmission cycles of tick-borne encephalitis virus may be disrupted by predicted climate change. Proc R Soc Lond B Biol Sci. 2000;267:1741-1744.

25. LoGiudice K, Ostfeld RS, Schmidt KA, Keesing F. The ecology of infectious disease: effects of host diversity and community composition on Lyme disease risk. Proc Natl Acad Sci U S A. 2003:100:567-571. 26. Glass GE, Cheek JE, Patz JA, et al. Using remotely sensed data to identify areas at risk for hantavirus pulmonary syndrome. Emerg Infect Dis. 2000; 6:238-247.

27. Trevejo RT, Rigau-Perez JG, Ashford DA, et al. Epidemic leptospirosis associated with pulmonary hemorrhage: Nicaragua, 1995. J Infect Dis. 1998:178. 1457-1463

28. Gleick PH. The World's Water: 1998-1999. Washington, DC: Island Press; 1998.

29. Curriero FC, Patz JA, Rose JB, Lele S. The association between extreme precipitation and waterborne disease outbreaks in the United States, 1948 1994. Am J Public Health. 2001:91:1194-1199.

30. RodoX, Pascual M, Fuchs G, Faruque AS. ENSO and cholera: a nonstationary link related to climate change? Proc Natl Acad Sci U S A. 2002;99:12901-12906. 31. Metz B, Davidson O, Swart R, Pan J, eds. Climate Change 2001: Mitigation: Contribution of Working Group III to the Third Assessment Report of the Intergovernmental Panel on Climate Change. Cambridge, England: Cambridge University Press; 2001. 